\title{
Kvinnor i avlönat husligt arbete
}

\author{
Tobias Karlsson \& Malin Nilsson
}

En återkommande iakttagelse om könsarbetsdelning i historiska såväl som samtida sammanhang är att kvinnor har haft sämre möjligheter att göra karriär. De delarbetsmarknader som varit öppna för kvinnor har kännetecknats av likriktade och standardiserade jobb som inte varit förknippade med lärande och möjligheter till socialt avancemang. Mycket av forskningen om mäns och kvinnors karriärmönster har handlat om arbeten på fabriker och kontor. I det här kapitlet riktar vi däremot uppmärksamheten mot en delarbetsmarknad som var särskilt viktig för kvinnor under det tidiga 1900-talet: husligt arbete.

\section{Tjänstefolk i husligt arbete}

I begreppet "husligt arbete" ingår en mängd uppgifter som behöver utföras i ett hushåll, däribland att handla, att hantera livsmedel, att laga mat, att stryka samt att upprätthålla ordning och renlighet i bostaden. Ibland ingår också att passa och uppfostra barn samt att vårda hushållsmedlemmar, och i vissa fall kunde husligt arbete kombineras med andra arbetsuppgifter, exempelvis i allmogehushåll på landsbygden och i städernas hantverkarhushåll. Efterfrågan på tjänstefolk var knuten till familjens livscykel. ${ }^{1}$

Tjänstefolk tillfredsställde emellertid inte endast rent praktiska behov utan också behovet av att manifestera social status och klasstillhörighet. ${ }^{2}$ Att ha tjänstefolk var en förutsättning för den livsstil som 


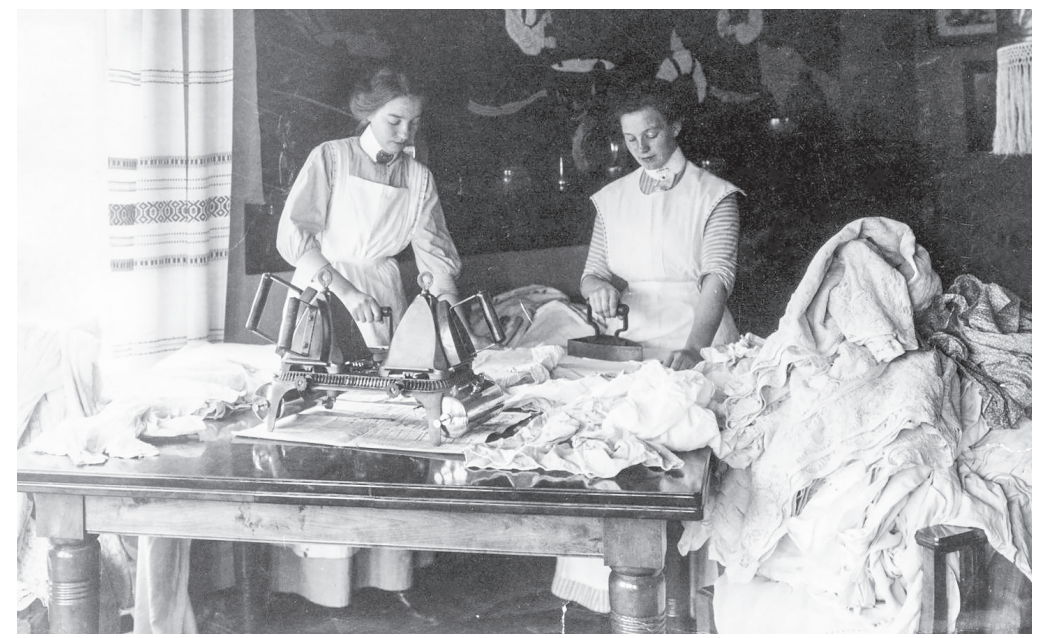

Bild 7.1. Interiör från ett borgerligt hem i Göteborg omkring 1910. På denna bild hettar tjänarinnor upp strykjärn på en särskild värmare. Foto: okänd, Göteborgs stadsmuseum.

välbeställda familjer vant sig vid. Som dottern till en biografägare i Göteborg konstaterade när hon såg tillbaka på sin uppväxt under 1940-talet, att hennes föräldrar "alltid hade hjälp i huset, aldrig behövde tacka nej till en bjudning eller resa, aldrig behövde jäkta för att hinna få disken färdig till TV-Aktuellt”. ${ }^{3}$

Tjänstefolk förekom även i mindre välbeställda hem, vilket levnadsberättelsen i textrutan på sida 175 illustrerar. Här handlade det inte enbart om att upprätthålla en livsstil och markera social status utan om att hjälpa en ensamstående man att kunna hålla ihop sin familj.

År 1920 fanns, som nämndes i kapitel 2, närmare 25 procent av Göteborgs sysselsatta kvinnor inom sektorn husligt arbete. Andelen minskade över tid men var fortfarande över 10 procent år 1940. Det husliga arbetet förknippades med underordning och ofrihet och tedde sig inte lika lockande som att jobba i butik eller på kontor. Arbetet som hembiträde attraherade främst unga kvinnor från den omgivande landsbygden och det betraktades som ett genomgångsyrke. ${ }^{4}$

Trots dess betydelse är vår kunskap om det husliga arbetet och dess utövare ofullständig och motsägelsefull. Det gäller inte minst 


\section{En arbetare berättar om hur fadern fick hjälp av hushållerska}

En moders död kunde få stora konsekvenser för en arbetarklassfamilj, vilket en man född 1902 och uppvuxen i Olskroken vittnar om:

Jag minns ingenting av mamma. Det blev besvärligt för pappa som blev lämnad ensam med fyra barn. Tack vare en faster och goda vänner klarades situationen ut. Min bror kom på ett barnhem på Gårda. En syster fick bo hos min faster på Kastellgatan och den andra systern hos vänner på S:t Pauligatan. Jag själv fick bo kvar hos pappa, som hade ett spisrum på Olskroksgatan 1. Han var snickare på Gamlestadens fabriker. Om dagarna var jag hos en familj i huset och om kvällarna och nätterna var jag hos pappa.

När informanten som sexåring skrevs in i skolan hade situationen förändrats:

Pappa hade nu fått en hushållerska som hjälp i hemmet. Då flyttade två av barnen hem till oss. Vi var alltså tre syskon samlade igen. (Nilsson 1979, S276)

innebörden i sektorns många olika yrkestitlar och hur de var relaterade till varandra i enskilda individers livslopp, exempelvis om vissa titlar representerade över- eller underordnad ställning i ett arbetslag.

Detta kapitel handlar om hur marknaden för husligt arbete fungerade och huruvida den erbjöd möjligheter till vertikal social mobilitet. För att undersöka det har vi tittat närmare på de olika yrkestitlar inom gruppen husligt arbete som förekom i Göteborgs befolkningspanel (GOPP). ${ }^{5}$ Vad var det för skillnad mellan ett hembiträde och en hushållerska? Var hushållerskan en arbetsledare för annat tjänstefolk eller var hon en ensamarbetande ersättare för en hustru? Innebar ett yrkesbyte från hembiträde till hushållerska att ens sociala status steg? Utifrån mantalslängderna och GOPP kan vi inte ge några uttömmande svar på dessa frågor, men vi kan visa på likheter och skillnader mellan yrkena med avseende på utövarnas ålder, inkomster och boendesituation. Vi kan också visa hur vanligt det var att en individ rörde sig mellan olika yrken inom sfären husligt arbete. Sammantaget ger dessa upplysningar en klart tydligare bild av arbetsmarknaden för husligt arbete i en större stad under 1900-talets första hälft än vad som getts i den tidigare forskningen. 


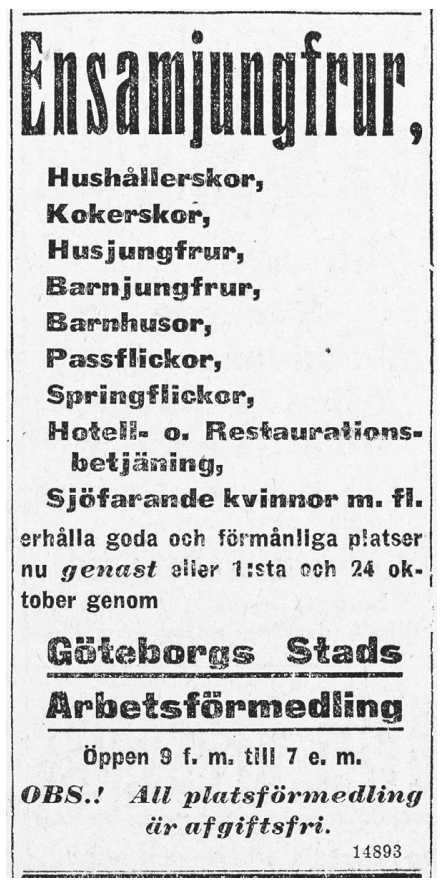

Bild 7.2. Göteborgstidningarna från 1900-talets första decennier innehåller gott om annonser efter tjänstefolk. Bland annonsörerna förekom privata och offentliga arbetsförmedlingar. Detta exempel är hämtat från Göteborgs aftonblad den 15 september 1915. Foto: Universitetsbiblioteket, Lund.

\section{Tidigare forskning om marknaden för husligt arbete}

Tjänstefolk i förindustriella samhällen har i forskningen ofta beskrivits i ett livscykelperspektiv (se kapitel 6). Unga män och kvinnor förväntades tjäna som dräng eller piga under unga år innan de etablerade egna hushåll. Det fanns en lagstiftning, legostadgan, som reglerade förhållandet mellan husbonden och tjänstefolket, vilket inte bara var ekonomiskt till sin natur utan även socialt. Även om tjänstefolket hade vissa rättigheter var relationen ojämlik. ${ }^{6}$ Arbetstiden var oreglerad; pigor och drängar förväntades arbeta närhelst husbonden så krävde. De var i allmänhet bundna till sin husbonde för ett år i taget.

I och med den tilltagande industrialiseringen och urbaniseringen under decennierna kring sekelskiftet kom alltmer tjänstefolk att arbeta 
i stadsmiljöer. Det skedde då en tydlig feminisering av yrkesgruppen. På landsbygden hade fördelningen mellan manligt och kvinnligt tjänstefolk varit tämligen jämn, men i städerna fanns manligt tjänstefolk endast i de mest välbärgade hemmen. Feminiseringen hade delvis att göra med den teknologiska utvecklingen. Tåg, spårvagnar och automobiler minskade exempelvis behovet av privata kuskar.

Arbetets innehåll och karaktär var annorlunda i staden, men den institutionella inramningen bestod länge. Ända fram till 1800-talets slut hölls i Göteborg pigmarknader i samband med Larsmässan i augusti, tills de förbjöds av myndigheterna. ${ }^{7}$ Därefter flyttade marknaden till arbetsförmedlingar och till dagstidningarnas platsannonser. Legostadgan fanns kvar fram till 1926, och tjänstefolk omfattades inte av den arbetstidslagstiftning och de kollektivavtal som annars reglerade stora delar av arbetsmarknaden. ${ }^{8}$

\section{Yrkestitlar}

I offentlig statistik och utredningar från mellankrigstiden framträder avlönade utövare av husligt arbete som en homogen skara. Även sentida forskare har haft en tendens att framställda det husliga arbetet som relativt enhetligt. I undersökningar av 1900-talets första hälft finns ett stort fokus på hembiträdena, som var den numerärt sett största yrkesgruppen på delarbetsmarknaden och som också lyckades organisera sig fackligt.

Det husliga arbetets homogenitet kan emellertid inte tas för given. Den år 1933 tillsatta Hembiträdesutredningen gjorde en uppdelning i olika specialiteter: ensamjungfrur, kokerskor, husjungfrur och barnsköterskor. Ensamjungfrurna arbetade som namnet antyder ensamma, medan husjungfrurna arbetade antingen med en annan husjungfru eller med en kokerska eller annat tjänstefolk med klart uttalad specialisering. I vissa sammanhang gjorde utredarna skillnad med avseende på utbildning och kvalifikationer, exempelvis mellan hembiträden "i allmänhet", "med särskild utbildning" och "andra kvalificerade". Det sistnämnda åsyftade hembiträden som hade relevant yrkeserfarenhet. Ensamjungfrurna utgjorde den i särklass största gruppen och deras andel ökade. ${ }^{9}$ 
Även historikern Sten Carlsson har påpekat att det inom sektorn förekom en rad yrkestitlar. ${ }^{10}$ Britt-Marie Ahlberg och Eva Dahl fann i sin studie av platsannonser i svensk dagspress 1880-1940 inte mindre än 56 olika benämningar på önskad arbetskraft inom fältet husligt arbete. ${ }^{11}$ Ahlberg och Dahl dokumenterade också hur yrkesbeteckningar dök upp och försvann över tid. Även i folkräkningarna, som delvis har blivit digitalt tillgängliga på senare år, framträder ett stort antal beteckningar på vad som kan förmodas vara avlönad arbetskraft i hemmen. Dock inte exakt samma som i platsannonserna - titeln "ensamjungfru", som var vanlig i platsannonserna, förekommer exempelvis knappast i folkräkningarna. ${ }^{12}$

Det kan tänkas att floran av yrkestitlar bara var olika benämningar på samma arbete. Såväl arbetsgivare som arbetstagare kan också ha haft intresse av att höja det husliga arbetets status genom att byta ut yrkestitlar. Vi kan iaktta hur "piga", den tidigare vanligaste benämningen för ogift kvinnligt tjänstefolk, ersattes av "tjänarinna", som i sin tur på 1920-talet ersattes av "hembiträde". Den senare förändringen initierades 1917 av Hanna Grönvall, aktiv i Stockholms tjänarinneförening. ${ }^{13}$

Samtidigt kan vi inte utesluta att förekomsten av olika yrkestitlar indikerar att det inom sektorn fanns inslag av vertikal och horisontell arbetsdelning, och därmed förutsättningar för social mobilitet. Det finns tidigare forskning som pekar i denna riktning och som motiverar att frågan undersöks närmare. Kerstin Moberg tillhör dem som i den sentida forskningen mest utförligt skrivit om det tidiga 1900-talets urbana hembiträden. Hon skriver att yrkestitlarna "varierade efter sysslans beskaffenhet och klargjorde därigenom den anställdas sociala ställning inom hushållet". ${ }^{14}$

\section{Hierarkier och rörlighet}

När det gäller tjänstefolkets mobilitet finns mer forskning om förindustriella, agrara, miljöer än om industristäder. Ekonomisk-historikerna Martin Dribe och Christer Lundh fann i sin studie av två skånska församlingar under 1800-talet att pigor och drängar flyttade relativt ofta mellan gårdar. ${ }^{15}$ Det fanns flera motiv till flyttningarna, däribland 
variationer i efterfrågan på arbetskraft och konflikter mellan hushåll och tjänstefolk. Folkminnesuppteckningar visar också att möjligheten att få mer ansvarsfyllda uppgifter kunde vara ett skäl att flytta. På de större gårdarna, som sysselsatte flera pigor och drängar, fanns förutom den horisontella arbetsdelningen mellan män och kvinnor, hierarkier där "förstapigan" hade arbetsuppgifter med högre status än "andrapigan" och så vidare.

Etnologen Angela Rundquist har beskrivit vertikal och horisontell arbetsdelning inom den svenska aristokratins hushåll under 180o-talets andra hälft. ${ }^{16}$ De smutsigaste arbetena utfördes av pigor (som senare kom att benämnas "jungfrur"), kokerskorna och deras medhjälpare lagade mat, och husor putsade silver. Därutöver fanns personliga tjänarinnor, exempelvis barnjungfrur och frökenhusor. Bland de personliga tjänarinnorna hade kammarjungfrun en särställning. Vidare skriver Rundquist:

Stora hus hade också en hushållerska eller husföreståndarinna. Hon kallades mamsell vilket uppfattades som en gradbeteckning. [...] omtalades gärna som fruns högra hand, en förlängning av husmors person, och var betrodd med att handha nycklar till linneförråd och handkammare. Eftersom hon var befriad från de smutsigaste arbetena var hennes händer nästan lika fina som matmoderns. ${ }^{17}$

Rundquist tillägger dock att yrkesbeteckningen "hushållerska" i vissa fall hade en helt annan innebörd:

En husföreståndarinna i ett ungkarlshem hade en makt som var i det närmaste likställd en ärbar husmors trots att hon inte tillhörde arbetsgivarens klass. Hon kunde även leva under äktenskapliga förhållanden med honom. I sådana förbindelser föddes barn i och några fall gjorde mannen en hederlig kvinna av mamsell och legitimerade barnen. Denna metod att skaffa sig en plats i överklassen var tveksam i någras ögon. ${ }^{18}$

1800-talets överklass i Göteborg hade en borgerlig snarare än aristokratisk identitet. Deras bostäder var inte adelsslott men kunde vara väl så praktfulla: "komforten var hög och tjänarnas skara stor. Då 
Karl XV 1860 gick husesyn i det dicksonska palatset i Allén trodde han inte sina ögon. [...] Lyxen syntes fullkomligt självklar för Dicksönerna", skriver Per Nyström. ${ }^{19}$ Med tiden torde tjänarstaberna ha blivit mindre. I det viktorianska Storbritannien gjorde högre löner i kombination med fallande landräntor att det genomsnittliga antalet tjänare per hushåll sjönk. Av de brittiska hushåll som år 1910 sysselsatte och härbärgerade tjänstefolk hade 80 procent bara en eller två tjänare..$^{20}$ Det blev inte bara svårare att rekrytera tjänstefolk, de som anställdes var i allmänhet unga och hade en stor benägenhet att röra på sig. ${ }^{21}$ Motsvarande utveckling går att skönja i Sverige, även om de riktigt stora hushållen aldrig var lika vanliga här. Enligt Therese Nordlund Edvinsson kunde det i hushåll inom den brittiska aristokratin en bit in på 1900-talet finnas över 20 tjänare. ${ }^{22}$ Hos välbeställda företagarfamiljer i samma land fanns dock sällan mer än fyra till sex tjänare. Det är också ungefär så många som den i Göteborg välbekanta familjen Broström hade på 1920-talet. ${ }^{23}$

Den svenska urbana medelklassen anpassade sig till bristen på tjänstefolk genom att anamma modern hushållsteknologi och flytta till något mindre bostäder. ${ }^{24} \mathrm{I}$ en studie av husligt arbete i olika länder menar Erna Magnus att utvecklingen tenderade att isolera tjänstefolket och försvåra den fackliga organiseringen.$^{25}$ Hon påpekade också att det husliga arbetet innebar få möjligheter till en yrkeskarriär och följaktligen av många unga kvinnor betraktades som ett tillfälligt jobb. Även Hembiträdesutred ningen lyfte fram att det husliga arbetet var en livsfas som föregick familjebildning. ${ }^{26}$

Kvinnoarbetskommittén betonade i sitt Betänkande angående gift kvinnas förvärvsarbete m.m. 1938 det avlönade husliga arbetets stora andel av kvinnors lönearbete, men de diskuterade inte närmare vilka yrkesgrupper som ingick i fältet. I förbigående gjorde de emellertid en intressant iakttagelse, nämligen att titeln "hushållerska" kunde beteckna en kvinna som levde i ett samboförhållande, ett så kallat stockholmsäktenskap, och utförde hushållsarbete i sitt eget hem. ${ }^{27} \mathrm{I}$ den offentliga statistiken räknades en sådan hushållerska som yrkesverksam, men så fort hon gifte sig försvann hon från arbetsmarknaden. 
Även Moberg uppmärksammar att yrkestiteln hushållerska kan ha haft olika innebörd. Hushållerskan fanns dels i hem där det saknades en husmor, dels i mer välbärgade hem, där hon stod högst i rang av tjänstefolket, hade ansvar för hushållets ekonomi och titulerades "husföreståndarinna". En indikation på hushållerskans status var att denna yrkeskategori vanligtvis placerades överst i dagstidningarnas platsannonser. ${ }^{28}$ Under hushållerskan fanns "kokerskan", som kunde ha hjälp av en "köksa". Under hushållerskan stod också "husan", som svarade för städning och servering. Fanns det två husor kunde den ena stå över den andra.

Den bild av den urbana arbetsmarknaden för husligt arbete som tecknas i samtida utredningar och sentida forskning bygger i stor utsträckning på kvalitativa belägg, även om det finns en del kvantitativa undersökningar av löneförhållanden. En av få sentida forskare som mer systematiskt har studerat individuella livslopp för tjänstefolk i städerna är Tine Susanne Jorde, som har skrivit om pigor och hembiträden i Stockholm under perioden 1880-1920. ${ }^{29}$ Jorde undersöker såväl geografisk och yrkesmässig rörlighet och riktar stort intresse mot arbetsgivarnas sociala stratifiering. Hon visar bland annat att tjänstefolk i allt mindre utsträckning kom att anställas av hantverksmästare och i allt högre utsträckning av högre tjänstemän och funktionärer, hos vilka de uteslutande hade arbetsuppgifter inom den rent privata sfären. ${ }^{30}$ Utöver deras sociala bakgrund uppmärksammar Jorde inte den sociala stratifieringen bland tjänstefolket. Hennes studie är avgränsad till kvinnor med yrkesbeteckningarna piga, tjänarinna och hembiträde och hon talar genomgående om det husliga arbetet som ett yrke.

\section{Husligt arbete i Göteborg under mellankrigstiden}

I GOPP finns totalt 595 observationer av kvinnor med yrkestitlar inom husligt arbete (HISCO-grupperna 224 och 540). "Hembiträde" är den vanligaste yrkestiteln, som anges i närmare hälften av fallen. Den titeln förekommer dock framförallt efter 1920. Näst vanligast är "tjänarinna", som anges i närmare en tredjedel av fallen, men den 
Tabell 7.1. HISCO-kategorier inom husligt arbete, Göteborg 1915-1943. Anm: Procentandelarna summerar inte alltid till 100 på grund av avrundning till heltal. Källa: Totalpopulationen, GOPP.

\begin{tabular}{lllcc} 
HISCO & Engelsk beteckning & Svenska yrkestitlar & Män & Kvinnor \\
\hline 22425 & $\begin{array}{l}\text { Housekeeper (private Service, } \\
\text { in hotels, or in other institutions }\end{array}$ & Husföreståndarinna, & 0 & 27 \\
22430 & Housfru & & \\
54010 & Domestic servant, general & Uppasserska & 0 & 81 \\
54020 & House servant & Hembiträde & 3 & 5 \\
54030 & Personal maid, valet & Tjänarinna & 1 & 270 \\
54035 & Nursemaid & Barnsköterska, passflicka & 0 & 26 \\
Totalt & & 4 & 595 \\
\hline
\end{tabular}

titeln uppvisar en kraftig nedgång efter 1916. Därutöver finns ett betydande antal observationer med yrkestitlarna "husföreståndarinna" eller "hushållerska" samt ett mindre antal med "uppasserska", "barnflicka" eller något liknande. Värt att notera är att yrkestiteln "piga" helt saknas i GOPP. I GOPP saknas också i stort sett titlar som direkt signalerar social stratifiering, exempelvis "1:a husa" och dylikt. Titlarna "ensamjungfru" och "husjungfru" förekommer ytterst sparsamt.

\section{Ålder och inkomst}

I tabell 7.2 redovisar vi genomsnittlig ålder i de vanligast förekommande yrkesgrupperna inom husligt arbete i GOPP. Det framgår att uppasserskor och barnflickor i genomsnitt var yngst, medan husföreståndarinnor och husfruar var äldre. Hembiträdena förefaller här ha varit signifikant yngre än tjänarinnorna, men det beror på att vissa tjänarinnor behöll sin yrkestitel långt upp i åldrarna. Typvärdet (den vanligast förekommande åldern) var för tjänarinnor 21 år och för hembiträden 23 år.

Hushållerskorna var konsekvent äldre än både tjänarinnor och hembiträden. Eftersom ålder i regel korrelerar med social status och yrkesskicklighet skulle det kunna tyda på att hushållsföreståndarinnor och hushållerskor hade en högre position än hembiträden, tjänarinnor, uppasserskor och barnflickor. 
Tabell 7.2. Ålder för olika yrkesgrupper inom husligt arbete, Göteborg 1915-1943. Källa: Totalpopulationen, GOPP.

\begin{tabular}{|c|c|c|c|c|c|c|c|}
\hline HISCO & Yrkestitel & $\mathrm{N}$ & Min & Max & Medel & $\begin{array}{r}95-1 \\
\text { konfic }\end{array}$ & $\begin{array}{l}\text { tigt } \\
\text { ervall }\end{array}$ \\
\hline 22425 & $\begin{array}{l}\text { Husföreståndarinna, } \\
\text { husfru }\end{array}$ & 27 & 20 & 70 & 39 & 34 & 44 \\
\hline 22430 & Hushållerska & 81 & 21 & 77 & 45 & 42 & 48 \\
\hline 54010 & Uppasserska & 5 & 17 & 31 & 23 & 16 & 30 \\
\hline 54020 & Hembiträde & 269 & 16 & 72 & 30 & 29 & 32 \\
\hline 54030 & Tjänarinna & 185 & 16 & 83 & 39 & 37 & 42 \\
\hline 54035 & Barnsköterska, passflicka & 24 & 16 & 38 & 24 & 22 & 27 \\
\hline
\end{tabular}

Mot bakgrund av den allmänna bristen på tjänstefolk under det sena 1800-talet har många historiker studerat tjänstefolkets löner i förhållande till andra kvinnliga yrkesgrupper. Sådana jämförelser kompliceras av det faktum att tjänstefolket förutom i kontanter också fick betalt i form av mat och logi samt att de till skillnad från andra arbetargrupper hade oreglerade arbetstider. Den bild som etablerats i den internationella forskningen är att kvinnor i husligt arbete hade väl så höga bruttoinkomster (kontanter och naturaförmåner) som andra kvinnor i yrken som inte krävde högre utbildning. ${ }^{32}$ Som historikern Tinne Vammen påpekar var dock arbetstiderna i regel betydligt längre inom husligt arbete, varför det är tvivelaktigt om de högre inkomsterna också innebar högre timlön. ${ }^{33}$ Ytterligare en komplicerande faktor är skillnaderna i årsarbetstid. Historikern Erik Sager menar att tjänstefolket inte bara hade längre arbetsdagar utan också fler dagar per år, vilket bidrog till högre inkomster. ${ }^{34}$ Med tanke på den tilltagande bristen på tjänstefolk i många länder borde inkomstgapet mellan husligt arbete och andra yrken ha ökat. Forskningen om detta är emellertid tunn och ger ingen entydig bild. I Kanada har Sager visat att kvinnor i husligt arbete tjänade mer än kvinnor i jämförbara yrken i slutet av 180o-talet men att skillnaden snarast minskade i början av 1900-talet. Arbetsgivarna tycktes inte ha varit beredda, eller kapabla, att erbjuda högre löner. Bland tjäna- 
rinnor i Köpenhamn under ungefär samma period menar Vammen att lönerna steg. ${ }^{35}$

Det finns också en del samtida undersökningar av den husliga arbetskraftens löner. Göteborgs hembiträdesförening genomförde 1929 en studie som visade på stor lönespridning. Ensamjungfrur tjänade mellan 40 och 80 kronor och hushållerskor mellan 40 och 90 kronor i månaden. ${ }^{36}$ Vi noterar att resultatet inte tyder på att hushållerskornas löner var väsentligt högre än hembiträdenas. Däremot tycks det ha funnits stora skillnader mellan olika arbetsplatser.

På nationell nivå presenterades i utredningen Arbetsförhållandena inom det husliga arbetets område 1936 en enkel analys av inkomstens bestämningsfaktorer inom det husliga arbetet. Det framgår att inkomsten ökade med stigande ålder och erfarenhet upp till en viss nivå, för att därefter stabiliseras, samt att tjänstefolk i mer välbeställda hushåll fick mer betalt. Ensamarbetande hembiträden (ensamjungfrur) tjänade $\mathrm{i}$ genomsnitt något mer än sådana som arbetade parvis eller $\mathrm{i}$ grupp (husjungfrur) men utredningen resonerar inte om eventuella skillnader mellan hushållerskor och hembiträden. ${ }^{37}$

I tabell 7.3 sammanfattas den information som finns i GOPP om inkomster av tjänst för kvinnor med yrkestitlar som indikerar husligt arbete. Det bör framhållas att vi har få observationer för vissa grupper och att observationerna dessutom är spridda över en tid när Sverige hade såväl kraftig inflation som deflation. Medelinkomsterna är därför osäkra. Dock kan vi se att hela 77 procent (208 av 269) av hembiträdena hade en deklarerad inkomst, att jämföra med 70 procent av hushållsföreståndarinnorna (19 av 27) och 48 procent (39 av 81) av hushållerskorna. Tjänarinnorna var den grupp där andelen som hade en deklarerad inkomst var minst, 36 procent (67 av 185). Av de fem observationer med yrkestiteln uppasserska var det bara en som hade en deklarerad inkomst.

Realinkomsterna låg på en likartad nivå för de olika yrkesgrupperna: någonstans mellan 550 och 700 kronor. Tjänarinnor hade lägst inkomster och barnsköterskor högst. Med en genomsnittlig realinkomst på knappa 600 kronor placerade sig hushållerskorna i den nedre delen. Hembiträdena tjänade i genomsnitt något mer än hushållerskorna. 
Tabell 7.3. Realinkomst av tjänst för olika yrkesgrupper, Göteborg 1915-1943. Anm: Realinkomster i 1914 års prisnivå. Konfidensintervall kan inte anges för kategorin "uppasserska" eftersom det där bara finns en enda inkomstobservation. Källa: Totalpopulationen, GOPP.

\begin{tabular}{llccccrr} 
HISCO & Yrkestitel & $\begin{array}{c}\text { Med dekl } \\
\text { inkomst }\end{array}$ & $\begin{array}{c}\text { Utan dekl } \\
\text { inkomst }\end{array}$ & $\begin{array}{c}\text { Median } \\
\text { (kronor) }\end{array}$ & $\begin{array}{c}\text { Medel } \\
\text { (kronor) }\end{array}$ & $\begin{array}{c}\text { 95-procentigt } \\
\text { konfidensintervall }\end{array}$ \\
\hline 22425 & $\begin{array}{l}\text { Husföreståndarinna, } \\
\text { husfru }\end{array}$ & 19 & 8 & 613 & 625 & 552 & 698 \\
22430 & Hushållerska & 39 & 42 & 574 & 597 & 539 & 654 \\
54010 & Uppasserska & 1 & 4 & 714 & 714 & - & - \\
54020 & Hembiträde & 208 & 61 & 651 & 644 & 626 & 663 \\
54030 & Tjänarinna & 67 & 118 & 489 & 546 & 517 & 575 \\
54035 & $\begin{array}{l}\text { Barnsköterska, } \\
\text { passflicka }\end{array}$ & 18 & 8 & 754 & 701 & 613 & 788 \\
\hline
\end{tabular}

Antalet inkomstobservationer för hushållerskor är dock begränsat, och skillnaden kan vara slumpmässig. För att förtydliga det har vi i tabellen lagt till ett 95-procentigt konfidensintervall som bygger på antagandet att inkomstuppgifterna är normalfördelade. Som synes överlappar konfidensintervallen för hushållerskor och hembiträden delvis varandra. Skillnaden i genomsnittsinkomst mellan de två grupperna kan därför inte betraktas som statistiskt säkerställd. ${ }^{38}$

Hur kommer det sig att hushållerskorna sällan deklarerade inkomster, och när de gjorde så tjänade mindre än andra yrkeskategorier inom husligt arbete, trots att de i genomsnitt var äldre? En möjlig förklaring är att hushållerskor i regel var anställda i mindre bemedlade hushåll. Lite längre fram i kapitlet tittar vi närmare på de hushåll som de olika kategorierna av tjänstefolk tillhörde.

\section{Tjänarinnorna blir hembiträden?}

Under undersökningsperioden skedde en markant nedgång i antalet kvinnor som registrerade sig som "tjänarinna". Det skedde också en motsvarande ökning i antalet hembiträden. Om vi lägger ihop kategorierna "tjänarinna" och "hembiträde" blir det sammantaget en nedåtgående trend mellan 1915 och 1943. Utvecklingen av dessa två yrkestitlar är alltså vad som ligger bakom den allmänt nedåtgående 
Diagram 7.1. Antal personer i husligt arbete per år och yrkestitel, Göteborg 1915-1943. Källa: Totalpopulationen, GOPP.

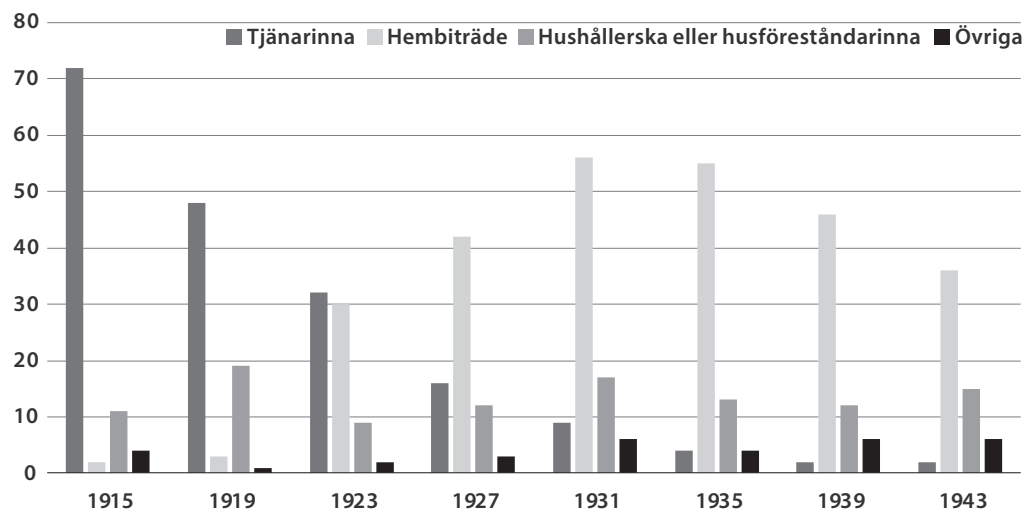

trenden i avlönat husligt arbete som vi såg i den aggregerade statistiken i till exempel kapitel 2. ${ }^{39}$

Hur såg mobiliteten ut mellan "tjänarinna" och "hembiträde"? Förekom det att kvinnor med den ena titeln bytte till den andra titeln? Vi har i materialet 121 kvinnor som någon gång stod som "tjänarinna" i mantalslängden. Tjugo av dem bytte från "tjänarinna" till "hembiträde", och endast två från "hembiträde" till "tjänarinna". De allra flesta som registrerade sig som "tjänarinna" gjorde det 1915; efter detta år var det få som inledde en yrkesbana med titeln "tjänarinna”.

Av de kvinnor som någon gång varit registrerade som "tjänarinna" bytte 38 titel under vår undersökningsperiod. Endast två bytte till "hustru" eller någon annan icke-titel, de andra bytte till yrken som låg nära husligt arbete: kokerska, tvätterska, diskerska, barnsköterskebiträde. Det tyder på att tjänarinna var ett instegsyrke eller i varje fall ett yrke med relativt låga trösklar till andra yrken inom samma område. Det var dock relativt många som blev affärsbiträden eller liknande och verkade ta del av den expanderande arbetsmarknaden för serviceyrken.

Även om vi tycker oss se klara indikationer på att "tjänarinna" och "hembiträde" i stort var samma typ av position är det inte uteslutet att bytet från "tjänarinna" till "hembiträde" innebar någon form av statushöjning. Men att döma av hur urvalet ser ut och vad vi vet 
utifrån tidigare forskning är det osannolikt. Istället verkar utvecklingen ha varit resultatet av en medveten facklig strävan att införa en ny yrkestitel. Huruvida denna nya yrkestitel höjde yrkets status i realiteten är en intressant fråga för fortsatt forskning.

\section{Hushållerska eller hembiträde?}

Så till frågan om skillnaderna mellan hushållerskor och hembiträden. Vi fann ingen skillnad i inkomst mellan dessa två yrkestitlar (se tabell 7.3), men hushållerskorna var genomgående äldre. I de följande avsnitten ska vi undersöka eventuella skillnader i boendesituation, hushåll och fortsatt yrkesliv mellan hushållerskor och hembiträden.

\section{Arbetsgivarens hushåll}

I detta avsnitt undersöker vi i vilken utsträckning hushållerskor respektive hembiträden tillhörde samma hushåll som sina arbetsgivare (var mantalsskrivna på samma adress) samt om det i så fall fanns annat tjänstefolk i samma familj. Vi kommer också att se på hushållsföreståndarens socialgruppstillhörighet, kön och civilstånd. Var det så att hushållerskor och hembiträden främst var anställda hos familjer i den övre medelklassen, eller kunde de lika gärna vara anställda av ensamstående män och fungera som ersättare för en hustru?

Eftersom GOPP endast innehåller information om urvalspersonerna (samt eventuell make/maka) gick vi till mantalslängderna för att inhämta kompletterande uppgifter. Vi kartlade samtliga hushållerskor från och med 1923 och ett lika stort urval av hembiträden, stratifierat efter panelår.

Vi delade in observationerna i tre grupper: (1) bor hos arbetsgivaren och är ensam som hushållerska/hembiträde, (2) bor hos arbetsgivaren och där finns ytterligare tjänstefolk och (3) bor inte hos arbetsgivaren (har istället eget hushåll, bor i föräldrahemmet, delar bostad med andra eller är inneboende hos någon annan än arbetsgivaren). I en färde grupp hamnade de observationer för vilka vi inte kunde fastslå boendesituationen. För grupp 1 och 2 klassificerade vi hushållsföreståndarens yrke med hjälp av HISCLASS. 
Tabell 7.4. Hushållerskors och hembiträdens boendesituation, Göteborg 1923-1943. Anm: Inom hakparenteser anges 95-procentigt konfidensintervall. Källa: GOPP; Göteborgs mantalskontors arkiv, mantalslängder 1924, 1928, 1932, 1936, 1940, 1944.

Boendesituation Hushållerska Hembiträde

(1) Bor hos arbetsgivare, inget annat tjänstefolk

31

2

13

(3) Bor ej hos arbetsgivare

(4) Obestämd boendesituation

$\mathrm{N}$

Andel av hushållsföreståndare i (1) och (2) som tillhör HISCLASS 1-4 (\%)

Av de 46 hushållerskorna i grupp 1-3 bodde 33 hemma hos sina arbetsgivare. I endast två av dessa hushåll fanns ytterligare tjänstefolk. Av hembiträdena levde 37 av 48 hemma hos sina arbetsgivare och åtta av dem arbetade tillsammans med andra hembiträden eller annat tjänstefolk, oftast ett annat hembiträde.

Tittar vi närmare på dem som levde hos sina arbetsgivare finner vi att 55 procent av de hem där hushållerskorna arbetade leddes av individer som tillhörde någon av de fyra översta samhällsklasserna enligt HISCLASS. Bland hembiträdenas arbetsgivare var motsvarande andel 65 procent. Det förefaller alltså som att hembiträdena oftare arbetade i hem med hög social status, men skillnaden är inte statistiskt säkerställd.

Det fanns också en annan skillnad mellan de hushåll där hembiträden respektive hushållerskor arbetade. I 16 procent (24 av 149) av de hushåll där hembiträdena arbetade var hushållsföreståndaren en kvinna, oftast en äldre änkefru eller till exempel en yrkesarbetande lärarinna. Inga av hushållerskornas arbetsgivare var kvinnor. I hushåll med ensamma män kan vi alltså förvänta oss att hitta en äldre hushållerska, och i hushåll med ensamma kvinnor fanns uteslutande hembiträden. Det bekräftar bilden av hushållerskan som en "ersättningshustru”. En kvinna i yngre 20-årsåldern kunde gå in och arbeta som hembiträde hos en äldre kvinna, men verkar inte ha kunnat gå in och arbeta som hushållerska i en ensam mans hushåll. Det tyder 
Tabell 7.5. Hushållerskors yrkestitlar fyra år senare, Göteborg 1915-1943. Källa: Totalpopulationen, GOPP.

\begin{tabular}{lrc} 
Yrkestitel år $t+4$ & N & Andel (\%) \\
\hline Hushållerska & 22 & 40 \\
Hembiträde & 3 & 5 \\
Annat yrke & 11 & 20 \\
Inget yrke & 19 & 35 \\
Totalt & 55 & 100 \\
\hline
\end{tabular}

Tabell 7.6. Hembiträdens yrkestitlar fyra år senare, Göteborg 1915-1943. Källa: Totalpopulationen, GOPP.

\begin{tabular}{lrc} 
Yrkestitel år $\boldsymbol{t + 4}$ & N & Andel (\%) \\
\hline Hushållerska & 4 & 2 \\
Hembiträde & 73 & 42 \\
Annat yrke & 53 & 31 \\
Inget yrke & 42 & 24 \\
Antal observationer & 172 & \\
Antal individer & 114 & \\
\hline
\end{tabular}

på att det fanns någon form av innehållslig skillnad mellan yrkena, men skillnaden kan också ha varit rent begreppslig. Arbetsuppgifterna var desamma, men den som arbetade ensam i ett hushåll lett av en man var hushållerska per definition.

\section{Skillnader $i$ yrkesmässig rörlighet}

Hur vanligt var det att en person växlade mellan yrkestitlarna "hushållerska" och "hembiträde"? För att ta reda på det utgick vi från kvinnor som var antingen hushållerskor eller hembiträden vid ett observationstillfälle och följde upp dem vid nästa observationstillfälle.

Tabell 7.5 visar utfallet för dem som vid utgångspunkten var hushållerskor. Av dem var 40 procent hushållerskor även fyra år senare. En nästan lika stor andel, 35 procent, saknade då yrkestitel, vilket indikerar att de hade lämnat den formella arbetsmarknaden. En betydande grupp, 25 procent (14 personer), hade bytt yrke, men av dem var det endast tre personer som hade bytt till titeln "hembiträde". En av de tre gick från "hushållerska" via "kokerska" till "hembiträde".

Bland de 114 individer som i utgångsläget titulerades hembiträde (tabell 7.6) var andelen som kvarstod med samma yrkesbeteckning ungefär densamma som bland hushållerskorna. Andelen som lämnade den formella arbetsmarknaden var dock klart mindre, 24 procent, vilket kan bero på att dessa kvinnor var yngre. En klart större andel än bland hushållerskorna hade ett annat yrke vid nästa observa- 
tionstillfälle: 33 procent. Det var emellertid bara fyra personer som hade bytt till benämningen "hushållerska".

När det gäller hushållerskor och hembiträden kan vi alltså observera tydliga flöden dels till andra yrken, dels ut från arbetsmarknaden, men knappast mellan dessa två yrkestitlar. Det styrker bilden av att det rörde sig om två separata yrken.

\section{Slutsatser}

En betydande del av de kvinnor i Göteborg som lönearbetade i början av 1900-talet var verksamma i andra personers hem. I det här kapitlet har vi undersökt denna arbetsmarknad närmare. Vi har bland annat intresserat oss för eventuella skillnader mellan olika yrkesbeteckningar och i vilken utsträckning individer rörde sig mellan olika positioner.

Våra resultat tyder på att den skarpa nedgången i antalet tjänarinnor inte innebar en faktisk nedgång i den typen av arbete, utan att det handlade om en begreppslig förändring där nyordet "hembiträde" tog "tjänarinnas" plats. Det är en viktig distinktion eftersom vi annars kan tolka det som en faktisk nedgång i en yrkeskategori och en skarp uppgång för en annan.

Våra resultat indikerar också att hushållerskor och hembiträden, till skillnad från tjänarinnor och hembiträden, utgjorde två distinkta grupper på arbetsmarknaden för husligt arbete i Göteborg under mellankrigstiden. Hushållerskor var i genomsnitt äldre än hembiträden. Deras yrkesbanor skilde sig också åt. Den som en gång titulerats "hushållerska" uppträdde sällan som "hembiträde" vid ett senare tillfälle, och vice versa. Samtidigt visar studien att förekomsten av de två yrkestitlarna "hushållerska" och "hembiträde" knappast var ett uttryck för vertikal social stratifiering bland utövarna av husligt arbete av det slag som ofta antagits i tidigare forskning.

Den hushållerska vi oftast möter i Göteborg under mellankrigstiden fungerade inte som arbetsledare för en stab av kvinnligt tjänstefolk. Hon var snarare ensam tjänare i ett hushåll som saknade en husmoder. Hennes arbetsgivare var ofta en ogift man eller änkling, och han tillhörde inte nödvändigtvis något av de övre sociala skikten. 
Det kan förklara varför hushållerskan i allmänhet, trots sin högre ålder, inte tjänade mer pengar än annat avlönat tjänstefolk, exempelvis hembiträden. Hembiträden förefaller något oftare ha arbetat tillsammans med annat tjänstefolk och i hushåll som förestods av medlemmar av samhällets högsta skikt.

Även om den brist på tjänstefolk som rådde under första halvan av 1900-talet tycks ha varit ett allmänt fenomen i industrialiserade länder kan det tänkas att den svenska marknaden för tjänstefolk avvek från hur det såg ut i länder med större befolkning. Rent numerärt var den svenska över- och medelklassen mindre och det var ovanligt med stora staber av tjänstefolk såsom förekom vid engelska gods under den edvardianska eran och senare. Utrymmet för långtgående horisontell och vertikal arbetsdelning, och därmed social stratifiering, var begränsat i svenska storstadsmiljöer. Som en konsekvens av detta erbjöd arbetsmarknaden för husligt arbete i Sverige få möjligheter att göra yrkesmässig karriär, vilket kan ha varit en bidragande orsak till att många unga kvinnor lämnade yrket efter en kortare tid.

\section{Noter}

1 Davidoff \& Hall 1987.

2 Brunnström 2014.

3 Institutet för språk och folkminnen (IFGH 06416).

4 Stenberg \& Fürst 2021.

5 För närmare presentation av GOPP, se kapitel 1 och appendix.

6 Uppenberg 2018.

7 Hallén 2019.

8 Calleman 2007.

9 Sociala meddelanden 1935(2), s 117-136.

10 Carlsson 1966, s 248.

11 Ahlberg \& Dahl 1974.

12 Se Riksarkivet. Folkräkningar (Sveriges befolkning), https://sok.riksarkivet.se/ folkrakningar.

13 Föreningen bytte samma år namn till Stockholms hembiträdesförening. Moberg 1978, s 223. Se även Wallensteen-Jaeger 1977, s 12. En tjänarinneförening förefaller också ha bildats i Göteborg 1907 på initiativ av det socialdemokratiska ungdomsförbundet; föreningen nämns i samtida dagspress men föga är känt om dess verksamhet. 1919 bildades Göteborgs hembiträdesförening, som sägs ha samlat ungefär 200 medlemmar. Föreningens verksamhet är väl dokumenterad från 1927 
och beskrivs i Stenberg \& Fürst (1921, s 165-173). Dess viktigaste fackliga fråga var förkortad och reglerad arbetstid.

14 Moberg 1978, s 11. Se även Carlsson 1966, s 55 f.

15 Dribe \& Lundh 2005.

16 Rundquist 1989.

17 Rundquist 1989, s 236.

18 Rundquist 1989, s 237.

19 Nyström 1990 [1978], s 36.

20 Horn 1975, s 23.

21 Horn 1975, s 24.

22 Nordlund Edvinsson 2012.

23 Brunnström 2014.

24 Nordlund Edvinsson \& Söderberg 2010.

25 Magnus 1930a,b.

26 Sociala meddelanden 1935(2), s 117-136; SOU 1937:16; SOU 1939:15.

27 SOU 1938:47, s 267.

28 Se Ahlberg \& Dahl 1974.

29 Jorde 1995.

30 Historikern Lotta Vikström (2004), som undersökt den mellanstora sågverksstaden Sundsvall under ungefär samma period, kom dock fram till att pigor ofta var anställda av handlare och hantverkare och därför sannolikt hade arbetsuppgifter som låg utanför rena hushållssysslor.

31 Även andra yrkestitlar kan i realiteten ha inneburit arbete i andra personers hem, exempelvis "kokerska" (HISCO 53100), "tvätterska" (56100) och "strykerska" (56065).

32 Katzman 1981, s 303-314; Lasser 1987; McBride 1976, s 64; Sutherland 1981, s 109110. Sten Carlsson (1968, s 249) har vad gäller svenska förhållanden en avvikande uppfattning och hävdar att lönen - inklusive naturaförmåner - var betydligt lägre för tjänarinnor än för andra kvinnliga låglönegrupper.

33 Vammen 1986, s 52-54.

34 Sager 2007, s 514.

35 Vammen 1986, s 52-54.

36 Stenberg \& Fürst 2021, s 169.

37 Däremot observerade utredarna att den minoritet av kvinnor i husligt arbete som var mödrar också hade lägre inkomster eftersom de var tvungna att ägna viss tid åt barnets skötsel (Wallensteen-Jaeger 1977, s 26).

38 Vi har också gjort regressionsanalyser med realinkomst av tjänst som beroende variabel där vi bland annat kontrollerat för individernas ålder och (inkomstuppgifternas) kalenderår. Inte heller dessa analyser har kunnat påvisa någon statistiskt signifikant skillnad i realinkomst mellan hushållerskor och hembiträden.

39 Den negativa trenden var inte lika tydlig när det gäller antalet hushållerskor. 